$\xi=$ 圆

\title{
Workload, Tenure Auditor and Industrial Specialization Auditors on Audit Quality with Audit Committee as Moderating
}

\author{
Daniel T. H. Manurung*, Andhika Ligar Hardika, Yati Mulyati, Mohd Haizam Mohd Saudi \\ Faculty of Economics Widyatama University Bandung, West Java, Indonesia \\ *Corresponding author E-mail: Daniel.togi@widyatama.ac.id
}

\begin{abstract}
This study aims to obtain empirical evidence on audit quality on workload, auditor tenure and auditor industry specialization with the audit committee as a moderating variable. The study population was conducted on non-financial companies listed on the Indonesia Stock Exchange, a total sample of 10 companies research using purposive sampling. The research method uses moderating variables. The results of this study indicate that the workload affects audit quality while audit tenure and auditor industry specialization do not affect audit quality. This study found evidence that the interaction between workload and audit committee affects audit quality while the interaction of audit tenure and industry specialization does not affect audit quality.
\end{abstract}

Keywords: audit quality, workload, audit tenure, auditor industry specialization, audit committee.

\section{Introduction}

Public accounting firms that are currently operating at industrial enterprises have to face a significant problem of the large workload due to a shortage of staff during the audit period. This problem can be understood because, in a short period of the audit, the auditor must complete a very heavy workload to obtain audit evidence based on the evidence of the company's financial statements during the audit. Besides, public accountants also have to carry out the audit engagement on several different clients at the same time. Audit engagement is dependent upon each client, and future audit engagements should confirm to the audit report within 60-90 days from the date of the end of the fiscal year. Excessive workload will lead to time constraints and the situation on the fatigue of work performed by the staff of the auditor and the auditor to obtain audit evidence in collecting audit opinion. As a result of audit quality is very doubtful [10].

In Indonesia, the public accounting profession is one of the professions that can provide great opportunities in the world of work. Public accounting profession in Indonesia has not been able to impact a big change for the client due to a lack of equal distribution of the public accounting profession. Developments in the industrial world are experienced today more, and more companies go public, and the non-go public is confronted by several regulatory government regulations such as No. 40 the Year 2007 regarding Limited Liability Company, which in article 68 paragraph 1 stipulated that the financial statements for the company with assets above 50 billion must be audited.

Until 2014, the data from the Center of Accounting and Assessment services (PPAJP/PPPK) shows that public accountants are active in Indonesia amounted to 944 people out of 1075 registered. Besides, it also noted there are only 388 active KAP with the total registered of KAP 893. It is seen that the growth of the number of public accountants in Indonesia experienced very slow growth. Thus, the right natural if the number of public accountants regis- tered in Bapepam LK (OJK) to audit listed company capital markets is not balanced by the number of issuers listed.

According to $[9,15]$, the workload is "busy season" that occurs at the beginning of the year because most companies have fiscal years that ended in December. Then, Public Accountants has a responsibility not only to pay attention to the number of clients but also need to consider the limited time to complete the audit process. BAPEPAM Decree No.36/PM/2003 has set obligations of each issuer to submit audited financial statements (as audited) no later than the end of the third month (90 days) after the date of the financial statements.

Audit quality is also affected by the auditor specialization. Auditors who have a specialist understanding and better knowledge of the internal control of the company, the company's business risk and audit risk in the industry. In [14] found that specialist auditors usually make less mistakes than the non-specialist auditors. In [2, 14] found that companies audited by the auditor specialists have a value lower discretionary accruals.

The audit committee will also affect the quality of the audit because of the audit committee responsible for assisting the board of directors in monitoring the financial reporting process by management [3]. The existence of an audit committee within the company can provide more supervision of management performance and provide timely and accurate information on the financial statements of the company. The existence of formal communication between audit committees, internal auditors, and external auditors will ensure internal and external audit process done well [13].

This research is a development of research [15], "workload, auditor industry tenure and specialization on audit quality by adding audit committee as a moderating variable" and research conducted [13] "Effect of auditor workload and specialization on audit quality with the audit committee as a moderating variable and adding variable company size, company profitability, leverage and KAP (Big4) size as a control variable, while in this study added the variable size and leverage as a control variable. 


\section{Literature Review}

\subsection{The relations workload influence audit quality}

The workload is how much the individual capacity is needed in completing a number of jobs that must be done by a certain time limit. According to [13], workload of an auditor may arise as a result of the number of clients that must be handled by the auditor is not balanced with the limited time available to carry out the audit process. According to [9], workload caused by "busy season" that occurs at the beginning of [9] the year because most companies have fiscal years that ended in December. Busy season occurred because the company must report performance results and financial activities during the year in the form of financial statements. In [9] found that during the busy season discretionary accrual rate increases resulting in decreased quality of audits. This is consistent with the results of research conducted by [7]

\section{$\mathrm{H}_{1}$ : The Workload effect on audit quality}

\subsection{The relationships audit tenure influence on audit quality}

The results of the research [6] found that there is a significant negative influence on the tenure of the discretionary accruals. This means that the longer tenure, the higher the auditor's ability to restrict actions of the accrual of management that will improve the quality of the audit. The results of this study are consistent with the results of the study $[5,8]$, which found that tenure negatively related to audit quality measured by accruals. According to [16] influence, the independence and competence to audit quality have a contradictory effect. The longer the period of assignment would enhance the competence to improve audit quality. While, the longer term assignments will also reduce the independence which can degrade the quality of the audit. If improving the competence and independence of an equally strong decline in the lead no significant relationship between tenure on audit quality.

\section{$\mathrm{H}_{2}$ : Relationships audit tenure on audit quality}

\subsection{The relations of specialization auditor influence to audit quality}

Auditor industry specialization is the auditor who has experience and knowledge of audit clients with the same industry. Auditor with clients in the same industry will have a better understanding of the special audit risk in the industry to understand the characteristics of the company to be more comprehensive. It is probable that every industry has a different nature of the business, accounting principles, accounting systems, and tax laws are different from each other $[12,15]$. According to [13] state auditor who specializes in a particular industry has sufficient capacity and knowledge compared with auditors who are not specialists. The research results [11] found that KAP industry specialization has a significant negative effect on discretionary accruals or equal to a positive effect on audit quality. This means that companies with auditor industry specialization have an excellent audit quality because it can lower the level of discretionary accruals.

\section{$\mathrm{H}_{3}$ : auditor industry specialization on audit quality}

\subsection{The interaction Workload with the audit committee on audit quality}

The research [13] found that the existence of an audit committee serves to reduce the negative effect of workload on audit quality and the results of these studies are consistent with the results of the study [15]. The results of these studies show a positive relationship between workload interaction with the audit committee of the accrual discretionary or equal to negatively affect audit quality. This shows that the existence of an audit committee in the compa- ny acts to weaken the relationship between workload on audit quality. The role of the audit committee can reduce the workload of auditors that may affect the reduction in audit quality.

$\mathrm{H}_{4}$ : The relationship of interaction workload with the audit committee on audit quality

\subsection{The Interaction with the audit committee the audit tenure on audit quality}

When the audit committee dutifully and actively performs its role to legislate mandatory rotation of auditors in the company, then the lack of auditor independence concerns due to the long period of engagement that can be resolved. This lack of independence due to long tenure may cause the kinship between auditors to degrade the quality of financial statements presented [15]. Results of research conducted [4] found that the higher the quality of the audit committee will affect the shortening of the period of the engagement between the Firm and its clients. This is because the quality of the audit committee will carry out their duties effectively when overseeing the external auditor. The quality audit committee would tend to shorten the period of the audit engagement between the auditor and the client to maintain the independence of auditors.

$\mathrm{H}_{5}$ : The relationship of interaction with the audit committee the audit tenure on audit quality

\subsection{Interaction auditor industry specialization to the audit committee on audit quality}

According to [15], researchers suspect would not be affected by the interaction between auditor industry specialization to the audit committee on audit quality due to the company being audited by the auditor industry specialization have experienced and have knowledge of audit clients in the same industry so that it has a greater understanding of the risk of a special audit on certain industries. Thus, the companies audited by the auditor industry specialization has a better audit quality. The condition causes the interaction between the audit committee with auditor industry specialization in these companies does not affect audit quality. According to [13], if the company has been audited by the auditors who specialize the audit committee has no effect on improving audit quality.

$\mathrm{H}_{6}$ : The relationship between auditor industry specialization interactions with the audit committee on audit quality

\section{Methodology}

This research was conducted by testing hypotheses to explain the relationship between dependent variables, independent variables and moderating variables. This research uses purposive sampling method. The sample was selected through a purposive sampling method based on certain criteria with a total sample of 10 companies namely: (1) Companies that have been listed on the Indonesia Stock Exchange (BEI) in 2014 and 2015, (2) Companies that publish annual reports and reports finance in 2014-2015, (3) Companies that use Rupiah in their annual reports and annual reports, (4) Public accounting firms that consistently submit Annual KAP reports to the Ministry of Finance's PPAJP (PPPK) during the period 3 years in a row, namely 2012-2014. Tests on research using BLUE (Best Linear Unbiased Estimator) and MRA (Moderated Regression Analysis) models to determine compression workload, auditor industry specialization, and audit engagement period for manufacturing companies listed on the IDX. 


\section{Results and Analysis}

\subsection{Regression Testing Results without interaction Hy- pothesis 1 to hypothesis 4}

The coefficient of determination (R2) shows an adjusted $\mathrm{R} 2$ value of -.349 while R Square is 0.250 . This indicates that $25 \%$ of audit quality variables can be explained by workload variables, industry auditor specialization, audit tenure and audit committee while other variables outside the regression model explain the remaining $75 \%$. (Table 1 ).

Simultaneous statistical test results, showing the $\mathrm{F}$ test results with a calculated $\mathrm{F}$ value of 0.417 expressed with a positive sign then the direction of the relationship is positive. The value statistically shows at a significance level of 0.791 which can be concluded that $\alpha=0.05$ is 0.00 which means that the significance value is $0.791>$ 0.05 , then Ho is accepted. This shows that the simultaneous influence of the independent variable (Workload, Audit Tenure, and Auditor Specialization Industry) has a significant positive effect on the dependent variable. (Table 1).

The results of partial testing (t-test) are used to show how far the influence of one independent variable individually in explaining the variation of the dependent variable tested at the 0.05 level of significance.

Table 1: Determination results, $F$ test results, partial tests ( $t$ test)

\begin{tabular}{|c|c|c|c|c|c|}
\hline \multirow[t]{2}{*}{ Model } & \multicolumn{2}{|c|}{ Unstandardized Coefficients } & \multirow{2}{*}{$\begin{array}{c}\text { Standardized Coefficients } \\
\text { Beta }\end{array}$} & \multirow[t]{2}{*}{$\mathrm{t}$} & \multirow[t]{2}{*}{ Sig. } \\
\hline & B & Std. Error & & & \\
\hline 1 (Constant) & 1.129 & 3.409 & & .331 & .754 \\
\hline Workload & -9.010 & 65.661 & -.123 & -.137 & .896 \\
\hline Audit Specialization & .370 & .485 & .378 & .763 & .480 \\
\hline Engagement Relations & -.127 & .336 & -.226 & -.377 & .722 \\
\hline Audit Committee & -.060 & .338 & -.112 & -.178 & .866 \\
\hline R Square & \multicolumn{5}{|c|}{.250} \\
\hline Adjusted R Square & \multicolumn{5}{|c|}{-.349} \\
\hline F Test & \multicolumn{5}{|c|}{.417} \\
\hline Significance & \multicolumn{5}{|c|}{$.791^{\mathrm{a}}$} \\
\hline
\end{tabular}

The above results can be explained that the constant value of positive 1,129 states that if the four independent variables are considered constant or no addition, then the average discretionary accruals is 1,129 . The coefficient of workload variable as big as 9,010 shows that every addition of workload of an auditor (Workload) of $1 \%$ will reduce discretionary accruals by $9,01 \%$. The coefficient of auditor industry specialization variable of 0,370 shows that every addition of auditor industry specialization of $1 \%$ will reduce discretionary accrual or equal to $0.37 \%$.

The audit tenure variable coefficient value of -0.127 shows that every additional audit tenure of $1 \%$ will reduce discretionary accruals or equal to $0.12 \%$. The audit committee variable coefficient value of -0.060 indicates that each additional audit committee of $1 \%$ will reduce the discretionary accrual or equal to $0.60 \%$.

\subsection{Regression test results with the interaction of hy- pothesis 5 to hypothesis 7}

The results of the regression coefficient test with the interaction of hypotheses 5 to 7 shows adjusted R2 value of -126 while R Square is 0.250 . This indicates that the workload variable with the audit committee, the audit committee and workload can only explain $12 \%$ while other variables outside the regression model explain the remaining $88 \%$. (Table 2).

The $\mathrm{F}$ Test results show that the calculated $\mathrm{F}$ value is 1.497 with a significance level of 0.308 . The significance level is greater than 0.05 , which can be concluded that all independent variables namely industry specialization auditors (SPEC), audit committees (KMTE) and the interaction between auditors of industry specialization (SPEC_KMTE) do not simultaneously affect audit quality. (Table 2)

Simultaneous statistical test results show the results of the F test with a calculated $F$ value of 0.665 with a significance level of 0.603 which can be concluded that $\alpha=0.05$, then $0.603(>0.05)$, then Ho is accepted. It can be concluded that all independent variables are workload (WL), Audit Committee (KMTE) and Workload with the Audit Committee (WL_KMTE) simultaneously affect audit quality. (Table 2).

Table 2: Determination results, $\mathrm{F}$ test results, partial test ( $\mathrm{t}$ test)

\begin{tabular}{|c|c|c|c|c|c|}
\hline \multirow[t]{2}{*}{ Model } & \multicolumn{2}{|c|}{ Unstandardized Coefficients } & \multirow{2}{*}{$\begin{array}{c}\text { Standardized Coefficients } \\
\text { Beta } \\
\end{array}$} & \multirow[t]{2}{*}{$\mathrm{t}$} & \multirow[t]{2}{*}{ Sig } \\
\hline & $\mathrm{B}$ & Std. Error & & & \\
\hline 2 (Constant) & 1.129 & 3.409 & & .331 & .754 \\
\hline Workload & -9.010 & 65.661 & -.123 & -.137 & .896 \\
\hline Engagement Relations & -.127 & .336 & -.226 & -.377 & .722 \\
\hline Audit Committee & -.060 & .338 & -.112 & -.178 & .866 \\
\hline R Square & \multicolumn{5}{|c|}{.250} \\
\hline Adjusted R Square & \multicolumn{5}{|c|}{-.126} \\
\hline F Test & \multicolumn{5}{|c|}{.665} \\
\hline Significance & \multicolumn{5}{|c|}{$.603^{\mathrm{a}}$} \\
\hline
\end{tabular}

\section{Discussion}

\subsection{Effect of workload on audit quality}

Based on the tests that have been done, the results of this study indicate that the workload variable (WL) has at a count of -0.137 with a significance level of $0.016(>0.05)$. That means H1 is accepted so that it can be said that the workload affects audit quality. The results of this study are consistent with [7, 9, 13, 15], which found that workloads affect audit quality. The more workload caused by the number of clients that must be done and the limited time can affect the audit quality produced. Whereas, according to research conducted by [1] who found that the workload did not affect audit quality. According to him, the number of assignments in the busy period at the beginning of the year does not make the auditor provide audit services that are not optimal because the auditor always adheres to the code of ethics and audit standards that require auditors to be professional in carrying out assignments. 


\subsection{Effect of audit tenure on audit quality}

The results of the t-test for the engagement relationship variable (TEN) have at-count of -0.377 with a significance level of 0.722 (>0.05). This means that $\mathrm{H} 2$ is rejected, so it can be said that audit tenure does not affect audit quality. This research is in line with [15] saying audit tenure does not affect audit quality. So, this research is consistent with the results of research conducted by [1, 16] researchers suspect that this indicates that the length of the audit engagement does not affect the audit quality produced. In contrast to the results of research conducted by $[6,16]$, themes have a positive influence on audit quality. According to him, this indicates that there is a possibility that the company maintains the same KAP with the consideration that the knowledge obtained by the auditor with a long engagement period will improve the audit quality of the financial statements.

\subsection{The influence of auditors on industrial specializa- tion on audit quality}

The results of the t-test for the industrial auditor specialization variable (SPEC) have a positive t count of 0.763 with a significance level of 0.480 (> 0.05). Meaning that, H3 is rejected. So, it can be said that the specialization of industrial auditors does not affect audit quality. This research is in line with research [15]. Researchers suspect that the auditor's ineffectiveness in industrial specialization on audit quality shows that there is no difference in audit quality between companies audited by KAP who are specialists and companies audited by non-specialist KAP. This is indicated by the mandatory regulation of audit rotation that allows each KAP to audit various types of companies with different types of industries so that KAP has experience in various industries.

\subsection{Effect of interaction between workload and audit committee on audit quality}

The Workload variable on the Audit Committee (WL_KMTE) which is the interaction between workload and audit committee has $\mathrm{t}-0.331$ with a significance level of $0.038(>0.05)$, so that it can be said that the audit committee variable is a moderating variable. This means that the workload with the audit committee affects audit quality. The results of this study are consistent with the results of research conducted by $[13,15]$.

\subsection{Effect of audit tenure interaction with the audit committee on audit quality}

The TEN_KMTE variable which is the interaction between audit tenure and the audit committee has t--0.304 with a significance level of $0.063(>0.05)$, so that it can be said that the audit committee variable is a moderating variable. This means that audit tenure with the audit committee does not affect audit quality. The results of this study are in line with research $[4,15]$

\subsection{Effect of auditor interaction on industry specializa- tion with the audit committee on audit quality}

SPEC_KMTE variable which is the interaction between industry auditor specialization and the audit committee has a tcount of 0.656 with a significance level of 0.149 (>0.05), so that it can be said that the audit committee variable is a moderating variable. This means that the specialization of industrial auditors with audit committees does not affect audit quality. The results of this study are consistent with the results of research conducted by $[13,15]$, which found that the interaction between auditors of industrial specialization and audit committees did not affect audit quality.

\section{Conclusion}

Based on the explanation of the research results, the Workload variable does not affect audit quality. This shows that the higher the auditor's workload does not have an impact on audit quality, the audit tenure variable does not affect audit quality. This means that the length of the audit engagement carried out by the public accounting firm does not have an impact on the audit quality produced, industrial audit specialization variables that industry auditors specialize does not affect audit quality. This means that the auditor's ineffectiveness in industrial specialization on audit quality shows that there is no difference in audit quality between companies audited by KAP who are specialists with companies audited by KAP who are not specialists. Meanwhile, the moderating variable Interaction between workload and audit committee on audit quality affects audit quality. The interaction between audit tenure and audit committee on audit quality does not affect audit quality. The interaction of auditor industry specialization with the audit committee on audit quality does not affect audit quality.

\section{References}

[1] Ardianingsih, A. (2013). Pengaruh Komite audit, lama perikatan audit dan audit capacity stres terhadap kualitas audit.

[2] Balsam, S., Krishnan, J., \& Yang, J. S. (2003). Auditor industry specialization and earnings quality. Auditing, 22(2), 71-97. https://doi.org/10.2308/aud.2003.22.2.71

[3] Bradbury, M., Mak, Y. T., \& Tan, S. M. (2004). Board Characteristics, Audit Committee Characteristics and Abnormal Accruals. SSRN Electronic Journal (Vol. 18). Unitec New Zealand dan National University of Singapore. https://doi.org/10.1108/01140580610732813

[4] Dyah Eka Putri, D., \& Nyoman Wiratmaja, I. D. (2015). Kualitas Komite Audit Memoderasi Pengaruh Masa Perikatan Audit Dan Spesialisasi Auditor. E-Jurnal Akuntansi Universitas Udayana, 2 570-587.

[5] Geiger, M. A., \& Raghunandan, K. (2002). Auditor Tenure and Audit Reporting Failures. AUDITING: A Journal of Practice \& Theory, 21(1), 67-78. https://doi.org/10.2308/aud.2002.21.1.67

[6] Giri, E. F. (2010). Pengaruh Tenur Kantor Akuntan Publik ( Kap ) Dan Reputasi Kap Terhadap Kualitas Audit: Kasus Rotasi Wajib Auditor Di Indonesia. Simposium Nasional Akuntansi XIII.

[7] Hansen, S. C., Kumar, K. R., \& Sullivan, M. W. (2008). Auditor Capacity Stress and Audit Quality: Market-Based Evidence from Andersen's Indictment. SSRN Working Paper Series, 6(202), 1-55.

[8] Johnson, V. E., Khurana, I. K., \& Reynolds, J. K. (2002). Auditfirm tenure and the quality of financial reports. Contemporary Accounting Research, 19(4), 637-660. https://doi.org/10.1506/LLTH-JXQV-8CEW-8MXD

[9] López, D. M., \& Peters, G. F. (2011). Auditor workload compression and busy season auditor switching. Accounting Horizons, 25(2), 357-380. https://doi.org/10.2308/a ch-10026

[10] Lu Tran Diem, T. (2016). The Effect of Auditor's Workload Pressure and Compression on Audit Quality. Oulu Business School. The University of Oulu.

[11] Rachmawati, Y., \& Fuad. (2013). Pengaruh Kualitas Auditor Terhadap Manajemen Laba (Studi Empiris pada Perusahaan Non Keuangan yang Terdaftar di BEI Tahun 2009-2011) DiponegoroJournal Of Accounting, 2(3), 1-9.

[12] Rusmawan Kusumah, R. W. (1992). pengaruh independensi akuntan publik, speslallsasl auditor dl bidang industri klien , dan karakteristik personal terhadap tingkat kepercayaan auditee ( Survey Pada Akuntan Publik Yang Terdaftar Di Bapepam-LK ). Indonesian Journal Of Economics And Business, 2(3).

[13] Setiawan W, L., \& Fitriany. (2011). Pengaruh workload dan spesialisasi auditor terhadap kualitas audit dengan kualitas komite audit sebagai variabel pemoderasi. Jurnal Akuntansi Dan Keuangan Indonesia, 8(1), 36-53.

[14] Solomon, I., Shields, M. D., \& Whittington, O. R. (1999). What Do Industry-Specialist Auditors Know? Journal of Accounting Research, 37(1), 191. https://doi.org/10.2307/2491403

[15] Suresti, A. (2013). Pengaruh Workload, Auditor Spesilisasi Industri dan Audit Tenure Terhadap Kualitas Audit Dengan Komite Audit Sebagai Variabel Moderating. Univesitas Islam Negeri Syarif Hidayatullah https://doi.org/10.1017/CBO9781107415324.004

[16] Wahyuni, N., \& Fitriany. (2012). Pengaruh Client Importance , Tenure, dan Spesialisasi Audit Terhadap Kualitas Audit. Simposium Nasional Akuntansi XV, 1-45. 